\title{
PSYCHOLOGICA
}

\section{Theories on intergroup relations and emotions: a theoretical overview}

Autor(es): $\quad$ Figueiredo, Ana; Valentim, Joaquim Pires; Doosje, Bertjan

Publicado por: Imprensa da Universidade de Coimbra

URL persistente:

URI:http://hdl.handle.net/10316.2/36849

DOI:

DOI:http://dx.doi.org/10.14195/1647-8606_57-2_1

Accessed : $\quad$ 26-Apr-2023 15:44:45

A navegação consulta e descarregamento dos títulos inseridos nas Bibliotecas Digitais UC Digitalis, UC Pombalina e UC Impactum, pressupõem a aceitação plena e sem reservas dos Termos e Condições de Uso destas Bibliotecas Digitais, disponíveis em https://digitalis.uc.pt/pt-pt/termos.

Conforme exposto nos referidos Termos e Condições de Uso, o descarregamento de títulos de acesso restrito requer uma licença válida de autorização devendo o utilizador aceder ao(s) documento(s) a partir de um endereço de IP da instituição detentora da supramencionada licença.

Ao utilizador é apenas permitido o descarregamento para uso pessoal, pelo que o emprego do(s) título(s) descarregado(s) para outro fim, designadamente comercial, carece de autorização do respetivo autor ou editor da obra.

Na medida em que todas as obras da UC Digitalis se encontram protegidas pelo Código do Direito de Autor e Direitos Conexos e demais legislação aplicável, toda a cópia, parcial ou total, deste documento, nos casos em que é legalmente admitida, deverá conter ou fazer-se acompanhar por este aviso. 


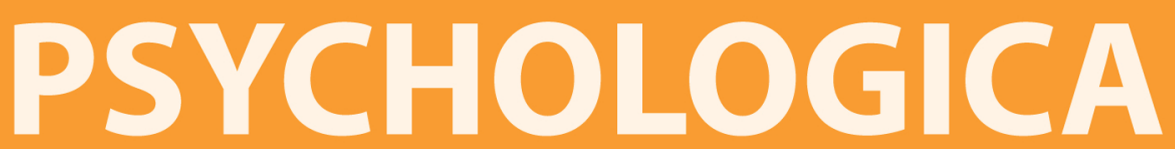




\title{
Theories on intergroup relations and emotions: A theoretical overview ${ }^{1}$
}

\author{
Ana Figueiredo ${ }^{2}$, Joaquim Pires Valentim ${ }^{3}$ and Bertjan Doosje ${ }^{4}$
}

\begin{abstract}
The present manuscript is a theoretical revision of the major theories about intergroup relations and emotions, developed over the last decades in the field of social psychology. Following a general chronological order, we first revise the first individualistic approaches to the field of intergroup relations and social conflict. Afterwards, we revise the realistic group conflict theory and relative deprivation theory. Next, we discuss the social identity and the self-categorization theories and highlight some of the most studied dimensions of intergroup relations within this framework. To conclude, we present some of the most influential appraisal theories of emotions and the theory of intergroup emotions. We claim for an integration of several different approaches when studying intergroup relations and, more specifically, the role of different emotions in explaining instances of intergroup conflict.
\end{abstract}

Keywords: theoretical revision; social identity; intergroup relations; emotions

1 This work was supported by a PhD grant from the Foundation for Science and Technology, Portugal [grant number SFRH / BD / 36056 / 2007].

2 University of Coimbra. Faculty of Psychology and Educational Sciences.Email:Figueiredo.anacm@gmail.com

3 University of Coimbra. Faculty of Psychology and Educational Sciences. Email: jpvalentim@fpce.uc.pt

4 University of Amsterdam. Email: e.j.doosje@uva.nl 
Teorias de relações entre grupos e emoções: Uma revisão teórica

\section{Resumo}

O presente artigo consiste numa revisão teórica das teorias mais influentes na área das relações entre grupos e das emoções, desenvolvidas ao longo das últimas décadas no campo da psicologia social. Seguindo uma ordem cronológica, primeiro apresentamos as abordagens individualistas no campo das relações entre grupos e do conflito social. Depois, revemos a teoria do conflito realista entre grupos e a teoria de privação relativa para, seguidamente, discutirmos as teorias da identidade social e da autocategorização e destacar algumas das dimensões das relações entre grupos mais estudadas dentro desta abordagem. Para concluir, apresentamos também algumas das teorias de avaliação (i.e. appraisals) das emoções e a teoria das emoções intergrupais. No presente artigo, defendemos a integração de várias abordagens e perspetivas diferentes ao estudar as relações intergrupais e, mais especificamente, ao analisar o papel das emoções na compreensão das relações entre grupos e do conflito social.

Palavras-chave: revisão teórica; identidade social; relações entre grupos; emoções

The social psychology of intergroup relations has a very long and rich history. Given its special attention, since the beginning, to phenomena such as racism (e.g. Stephan \& Stephan, 1996; Vala, Brito, \& Lopes, 1999), prejudice (e.g. Mackie \& Smith, 2003; Stephan \& Stephan, 1996), stereotyping (e.g. Deschamps, 1984; Turner, Hogg, Oakes, Reicher, \& Wetherell, 1987; Turner, 1999), discrimination (e.g. Ajzen \& Fishbein, 1977; Mackie \& Smith, 2003) and conflict, it is thus understandable how it became such a prolific area of research and theorizing.

Independently of the focus on societal groups, such as racial or ethnic groups, national groups, religious groups, work groups, or even, artificial groups, just to name a few, the focus on the interactions of people belonging to groups and perceiving, thinking about and acting towards other individuals who are also part of groups (be them ingroups or outgroups) presently sets the framework of analysis in intergroup relations.

One of the most widely known definitions of intergroup relations was provided by Sherif (1962) and states that

Intergroup relations refer to relations between two or more groups and their respective members. Whenever individuals belonging to one group interact, 
collectively or individually, with another group or its members in terms of their group identifications we have an instance of intergroup behavior. (p. 5)

Although this definition highlights the need to look at individuals as belonging (or not) to different groups in a way to comprehend their behavior towards other individuals who belong (or not) to the same groups, a long time of research and advances was necessary until we came to such an understanding of intergroup relations.

The first theories analyzing prejudice (i.e. "a positive or negative evaluation of a group and its members", Mackie \& Smith, 2003, p. 1), and discrimination (i.e. "negative behaviors directed towards members of socially defined groups because they are members of this group", Stephan \& Stephan, 1996, p. 35), focused mostly on the individual level of analysis and tried to explain discriminatory behavior from the perspective of individual differences and personality traits.

For example, in the 1930s and 1940s, the predominant explanations of prejudice were based on psychodynamic explanations of individual behavior, which focused on concepts such as projection, scapegoating, frustration and hostility displacement to explain the tendency of (some) individuals to be prejudiced towards others (Stephan \& Stephan, 1996). For example, in a study by Ackerman \& Jahoda (1950), using a sample of psychiatric patients, it was found that there is an association between racial prejudice and symptoms such as depression, psychopathic deviations and hypomania. However, these links were not found among samples without psychiatric disorders, thus leading to the idea that highly prejudiced and low prejudiced individuals may not differ according to these variables (Ackerman \& Jahoda, 1950).

Later, in the 1950s, the authoritarian personality theory (Adorno, FrenkelBrunswick, Levinson, \& Sanford, 1950) became famous in an attempt to explain the success of Nazi ideology in Germany.

The main assumption of most of these theories was that, for people to behave in such a negative and condemning manner there had to be something wrong with them as persons. Summarizing, the focus of analysis of these theories was on the individual, its behavior and the personality traits, which could potentially cause him or her to discriminate and be prejudiced.

Nevertheless, this personality and individual differences approach to prejudice and discrimination could not account for many instances of negative behavior occurring in many societies throughout the world. Additionally, the widely spread occurrence of prejudice and discrimination could not be explained by individuals' personal tendencies to become mean or evil. Consequently, as Pennekamp (2008) adequately declares, "given the fact that prejudice and discrimination mainly arise when a group's identity is salient, there has to be something about groups that causes (large parts of) its members to engage in discrimination" (p. 7). 
Summarizing, given the defaults of this approach and the lack of potential explanatory power for certain societal phenomena, new approaches and theories were developed, with the aim of explaining intergroup relations marked by prejudice, discrimination or even conflict. Consequently, since the beginning of the $1960 \mathrm{~s}$ and 1970s, sociocultural explanations gained relevance in the field of intergroup relations. Still, it is important to note that individual level and sociocultural level explanations are not mutually exclusive. We should bear in mind that individual and societal forms of prejudice may reinforce each other and go hand in hand when individuals find justifications for the existence of prejudice and discrimination (Stephan \& Stephan, 1996). One example of this interplay between both approaches is the belief in a just world hypothesis (Lerner, 1980). Its main assumption is that victims of discrimination or even mass violence must have done something bad and therefore, deserve the consequences brought upon them. Clearly, these self-fulfilling biases serve as a way to disregard societal responsibility for collective violence and conflict and may influence negatively intergroup relations and cooperation.

Given this general introduction, the following sections of this manuscript aim to present and reflect upon some of the most influential theories in the field of intergroup relations, which have a sociocultural focus, when explaining prejudice and discrimination.

\section{REALISTIC GROUP CONFLICT THEORY}

The first systematic attempt of going beyond the individual level approach to explain prejudice and discrimination, came to us in the 1960 s, by the hand of Muzafer Sherif (1966; Valentim, 2010). In his theorizing of intergroup conflict, he claimed that social groups relate to each other in terms of functional relations and thus, are interdependent. The author also assumes that groups set up goals for themselves and strive to achieve them. When two or more groups are positively interdependent or their goals do not interfere with the other groups' goals, relations can be cooperative and positive. However, when different groups set the same goals for themselves, their interdependence becomes incompatible and competition rises. This competition over scarce resources (be them natural, territorial, wealth or power related) can create antagonist relations and thus impel divergence amongst the groups, which could lead to violence and conflict (Sherif, 1966; Valentim, 2010).

This theory has received much empirical support and the famous Robbers Cave experiments are the primordial example of applicability of the theory. In these experiments (Sherif, Harvey, White, Hood, \& Sherif, 1961), they use a summer camp setting, 
in which they divided 22 boys into two groups and created a context in which the goals of both groups would be conflicting. This lead, as expected, to hostility and conflict between both groups. Later on, however, they were given goals that, to be fulfilled, required the cooperation between the two groups. This superordinate goal was then able to unite both groups and create positive and cooperative intergroup relations.

Drawing from the previous points, we can conclude that groups with conflicting interests will become antagonistic in relation to each other when they cannot fulfill their goals and desires in interdependence. This theory thus claims that instrumental reasons lie at the heart of intergroup conflict and, once these negative instrumental factors disappear, intergroup relations will become peaceful.

Although this theory has contributed enormously to the field of intergroup relations, some downfalls of this conceptualization should be made explicit.

First, history has given us many examples of intergroup conflict happening worldwide that do not occur due to realistic or instrumental reasons. As it will be discussed later in this manuscript, Tajfel (1970), using the minimal group paradigm, was able to prove that the mere categorization of individuals as members of a group will create intergroup discrimination, in conditions of low ingroup affiliation and absence of conflicts of interest or previous intergroup hostility.

As Tajfel and Turner (2001) state:

An institutionalized or explicit conflict of 'objective' interests between groups, however, does not provide a fully adequate basis, either theoretically or empirically, to account for many situations in which the social behavior of individuals belonging to distinct groups can be observed to approach the 'group' extreme of our continuum. The conflict in Sherif's studies was 'institutionalized', in that it was officially arranged by the holiday camp authorities; it was 'explicit' in that it dominated the life of the groups; and it was 'objective' in the sense that, by terms of competition, one of the groups had to be the winner and the other the loser. And yet, there is evidence from Sherif's own studies and from other research (...) that institutionalization, explicitness and 'objectivity' of an intergroup conflict are not necessary conditions for behavior in terms of the 'group' extreme, although they will prove to be sufficient conditions." (p. 95)

Secondly, Sherif's conceptualization does not address the role of group membership and identification in the formation, maintenance and resolution of intergroup conflict. The main focus of the theory in realistic and objective conflicts relegates the dynamics of social identity and intragroup processes to a secondary level and, therefore, the processes underlying the structure, development and change of social identities over time are not taken into consideration. 
According to this theory, the only possible ways of resolving conflict would be through the objective and fair partition of the scarce resources creating the conflict or through the creation of superordinate goals. While the first proposition may be a very hard venue of intervention given the world's present day conjecture, the latter has proved to improve intergroup relations (Sherif, 1966; Valentim, 2010). In this vein, further theoretical approaches have provided more detailed and coherent descriptions of intergroup processes and discrimination, namely, relative deprivation theory, which states that intergroup tensions and conflict may actually arise from perceptions of disadvantage rather than real disadvantage regarding resources (be them natural or symbolic, amongst others).

\section{RELATIVE DEPRIVATION THEORY}

In contrast with the realistic group conflict theory, relative deprivation theory assumes that feelings of deprivation stem not from real objective lack of resources, but more from the comparison made by individuals or groups with other individuals or groups, who might be advantaged in relevant dimensions of the comparison terms.

Relative deprivation theory thus argues that the subjective differences between individuals or groups may lead to perceptions of disadvantage, and this analysis of the inter-individual or intergroup relations may cause attrition or even conflict.

The first time the concept of relative deprivation was used came by the hands of Stouffer, Suchman, DeVinney, Star and Williams (1949) to describe, at post hoc, differences in satisfaction between elements of the United States Army during the Second World War. In this study, the authors found that, sometimes, there was no need for objective inequities to exist for individuals to feel deprived. However, over the years, the notion of relative deprivation lost support and value as an explanatory social psychological concept and it was only in the 1990s that it was brought up again in an attempt to understand social movement participation (for a detailed overview see Walker \& Smith, 2002).

In the development of the relative deprivation literature, a theoretical distinction has been made between deprivation at the individual level and deprivation at the group level. Regarding deprivation at the group level, relative deprivation theory benefits from the conceptualizations of social identity theory and self-categorization theory (Tajfel \& Turner, 1986; Turner et al., 1987), when it assumes that feelings of relative deprivation will have different characteristics and consequences if they are felt on behalf of personal identities (egoistic deprivation) or social identities (fraternal deprivation). 
In terms of intergroup relations, relative deprivation is felt when one's ingroup is compared to a relevant outgroup and is perceived as disadvantaged in this comparison. Especially when groups make upward comparisons, meaning that the selected outgroup has more power, status or wealth, there is a higher chance that deprivation will be felt.

In addition, there is also the possibility of distinguishing between people who experience only personal deprivation, people who report both personal and group deprivation (which was coined as double deprivation by Vanneman \& Pettigrew, 1972) and people who report group deprivation but no personal deprivation. This differentiation, of course, presents consequences for the strategies used by individuals who want to change the status quo in dimensions or contexts in which they feel deprived.

As Smith, Spears and Hamstra (1999) affirm, "different levels of identity salience primed in the social context (personal versus group identity) are expected to evoke different levels of social comparison (interpersonal versus intergroup), which then help to explain feelings of deprivation and associated behavioral outcomes" (p.209).

More specifically, in an attempt to describe the several strategies used by individuals to diminish their feelings of group deprivation, Smith and colleagues (1999) refer that

The chances of people responding collectively to their group's fate will be maximized when their group identity is salient (context), when they identify strongly with the group (commitment) and when collective group behavior is ideologically consistent with group norms (content). (p. 229)

Although we have now described, briefly, some of the preconditions for relative deprivation to occur, we should still describe how these subjective feelings of dissatisfaction may shape intergroup relations and conflict. In this line, we consider relative deprivation theory as a complementary analysis of intergroup relations within the framework of the social identity perspective and, therefore, we will now try to describe in more detail the conceptualizations of social identity theory regarding intergroup relations.

\section{SOCIAL IDENTITY THEORY}

Social identity theory, before coming into existence, drew its principles from the "gestaltic" tradition of research, which had shown that individuals overestimate the perception of objects or physical stimuli with attached value to them, due to a basic process of categorization of these same objects or stimuli into meaningful categories (for a detailed revision see Amâncio, 2002 and Valentim, 2003). 
Within the tradition of the metatheory of social psychological interactionism, it is assumed that certain psychological processes are socially constructed, structured, and transformed through the interaction with social life and processes (Turner \& Reynolds, 2001). In this line, the application of the "gestaltic" principles mentioned above was introduced and developed in relation to the dynamics of social life by Tajfel and Turner (1979).

The first studies using the minimal group paradigm, thus mark the initial conceptualizations of the social identity approach. In these studies, it was shown that the mere categorization in terms of an ingroup and an outgroup created instances of discrimination between the members of the different groups (Tajfel, Flament, Billig, \& Bundy, 1971).

As Turner (1999) states, "the mere social categorization of subjects in the minimal group paradigm created a social identity for them. The subjects accepted the assigned social category membership as a relevant self-definition in the situation.” (p. 8)

Within the social identity theory, after defining social identity as those aspects of a person's self-concept or image that derive from the social categories to which they belong to, Tajfel and Turner (1979) developed three general assumptions of the theory.

The first of these assumptions relates to the distinction between personal identity and social identities. Tajfel and Turner (1979) propose that every individual's self is structured within a continuum having two extremes by which behavior can be defined. At one extreme, more personal and idiosyncratic aspects of individual identity will be more salient and any interaction with other individuals will be based on individual characteristics and motivations. At the other extreme, the interactions between two or more individuals will be based on aspects referring to their social identities as members of different (or the same) groups. At this extreme position of the continuum, the self-definition of individuals will carry with it the associated value connotations of social group memberships. Therefore, the content of specific group behaviors lies on the basis of the salient social identity underlying them. As the authors also refer, it will be extremely rare to find situations in which interactions between individuals only occur at one extreme or the other of the continuum.

Tajfel used the interpersonal-intergroup continuum to explain when social identity processes are likely to come into operation and how social interaction differs qualitatively between the extremes. He argued that, as behavior became more intergroup, attitudes to the outgroup within the ingroup tend to become more uniform and consensual and outgroup members tend to be seen more as homogenous and undifferentiated members of their social category. (Turner, 1999, p. 9-10)

An important aspect of their theorizing relates to the motivational aspects of social identities, by which individuals strive to maintain or enhance their selfesteem through their social identities. In this line, the second principle does become 
clear: to maintain or enhance their self-esteem, members of social groups will base their comparisons with relevant outgroups with which they can make a favorable comparison on behalf of the ingroup.

The basic premise, then, is that, through a process of social categorization leading to social identity and social comparison with relevant outgroups, members of the ingroup would achieve positive intergroup distinctiveness, and a positive self-evaluation in terms of that social identity.

Therefore, stemming from this principle, it is important to bear in mind the conditions in which intergroup differentiation will occur. First, individuals must feel subjectively identified with their ingroup. The mere categorization of the individual made by others may not be relevant for this internalized identity and, henceforth, if the individual does not want to be or feel part of the group, this distinction will not occur. Secondly, the differentiation must occur only when attributes which distinguish the groups are relevant and have evaluative significance. Third, group members do not compare themselves with every available outgroup. Instead, they choose relevant outgroups with whom to compare and differentiate positively.

Finally, the third principle of social identity theory relates to the possibility that groups to which one belongs may not satisfy the motivational principle of maintaining a positive self-esteem and intergroup differentiation. Therefore, when social identity is unsatisfactory, members of the group may act in terms of different strategies to avoid this negatively evaluated social identity.

For Tajfel and Turner (1979) the character of intergroup attitudes and action is predicted by an interaction between the need for positive social identity and group members' collective definition, perception and understanding of the social structure of intergroup relationships. (...) Groups would adopt quite different strategies to achieve positive social identity (and ingroup bias or 'social competition' is only one of these strategies) as a function of an interaction between their status position (high or low), their beliefs about the nature of group boundaries, the intensity of ingroup identification and their collective ideologies of status, power and wealth. (Turner, 1999, p. 9)

Following this reasoning, social identity theory assumes that group members may use different strategies when a negative comparison with a relevant outgroup is inevitable. In this line, a typology of the different strategies individuals might use when confronted with a negative social identity was created, and rests its bases on three socio-structural factors: perceptions of the permeability of group boundaries (i.e. to what extent can one leave the group and enter another group), the groups' status legitimacy and their status stability (Ellemers, 1993; Tajfel, 1978). 
The first strategy that individuals can use to address their negatively evaluated social identity is named "individual mobility", which is more focused on individual behavior aimed at achieving a more positive situation for the individual, but not for the entire group. This strategy can only happen when the group boundaries are perceived to be permeable and when there is the possibility for an upward change in the social status of the individual (Tajfel \& Turner, 1979).

Secondly, individuals can recur to what is called "social creativity", by redefining or changing the elements which are causing the negative comparative situation. In this line, it is not necessary that the intergroup conditions are changed, but that the differentiation is made differently. This is a group strategy which can take three different forms. When possible and legitimate, groups may change the relevant dimensions in which they are compared negatively to relevant outgroups. Otherwise, groups may change the value assigned to the dimensions which, in first place, set the group in a downward comparison, thus creating a new positive definition of the attributes or dimensions at stake. Another possibility is that devalued groups change the outgroup with which they compare themselves and select a new outgroup for the comparison to bring about positive differentiation (Derks, Van Laar, \& Ellemers, 2007).

Finally, the third strategy is "social conflict" instigated by the ingroup via direct competition with the relevant outgroup. This strategy can only happen when the status differences between the groups are seen as unstable and illegitimate and the group boundaries are impermeable. It may bring about more tension in the intergroup relations, but it may also create an environment of social change, by which the ingroup is finally acknowledged its positive differentiation and change in status.

Summarizing, for social identity theory, the key factors influencing behavioral shifts along the individual-social identity continuum towards the more collectivist pole were the group's impermeable boundaries and the social change belief-system, and these conditions would be the determinants of collective reactions of ingroup members in a disadvantaged position (Tajfel \& Turner, 1979).

Although the authors assume that there is a qualitative psychological difference between individual and group behavior, they do not specify the processes by which this differentiation may occur and, in an attempt to overcome this lack of explanation, Turner (1981) moves on to create the self-categorization theory.

\section{SELF-CATEGORIZATION THEORY}

In self-categorization theory (Turner et al., 1987), although some of the principles of social identity theory remain untouched, there is a greater emphasis on the 
cognitive aspects and functions of self-categorization in social identity processes. Therefore, it is proposed that self-categorization, leading to self-stereotyping, is the process by which group behaviors come to existence.

When people categorize themselves in terms of a shared social membership, there is a tendency to accentuate intragroup similarities and intergroup differences in relevant dimensions of comparison with other groups. Furthermore, in self-categorization theory, the relative salience of a given social identity in a specific social context is given prominence. In this line, the most relevant aspect of social identity in a given context is the extent to which a social category becomes salient, as a result of its relative accessibility and accurate application in the situation (Turner, 1999).

This salient categorization leads people to stereotype themselves and others, creating an enhanced perceptual contrast between ingroup members and outgroup members. Whenever this relevant social identity becomes salient, then, individuals will perceive themselves less as distinct and unique persons and more as prototypical representatives of their ingroup.

The distinction between individual and group behavior can be explained by a parallel and underlying distinction between personal and social identity (...). Hence, individual identity is matched with interpersonal behavior and social identity with intergroup behavior and social identity was reconceptualised as the process which transforms interpersonal into intergroup behavior. (Turner, 1999, p. 9-11)

Following the rationale presented above, Turner (1999) thus assumes that there is a depersonalization effect of the self when self-categorization in terms of a salient social identity occurs. Social identity thus becomes the social categorical self and, when a given social identity is made salient, self-perception becomes depersonalized, leading individuals to see themselves as interchangeable representatives of the relevant social category at stake.

At this point, Turner and colleagues (1987) introduce an important redefinition of the link between personal identity and social identities present in social identity theory. In opposition to the conceptualization in social identity theory of a continuum in which there are two extreme poles (individual and social) of categorization, selfcategorization theory postulates that these different self-conceptions are distinct levels of self-categorization, which function antagonistically in relation to each other. In other words, the different levels of self-categorization function oppositely in relation to each other and the salience of one level of self-categorization undermines the effects of other levels of inclusion, by which intra-class similarities and inter-class differences come to existence. Thus, the functional antagonism between the different 
levels of inclusion implies that, when a social category is made salient, the perception of intragroup differences and intergroup similarities will be suppressed.

Additionally, given the new conceptualization of self-categorization in terms of salience of different levels of self-definition, Turner and colleagues (1987) introduce a hierarchical self-categorization system.

This system presents three major categories, by which individuals can self-categorize: the less inclusive, more subordinate level of self-categorization is the one in which individuals categorize themselves as distinct persons. The intermediate level of inclusiveness refers to ingroup-outgroup comparisons in which accentuation of ingroup similarities and outgroup differences occur. Finally, the human being category is the superordinate, most inclusive level of self-categorization by which the commonalities of the human species are contrasted with other forms of life (Turner et al., 1987).

Moreover, Turner and colleagues (1987) postulate that the variation in the salience of the different levels of self-categorization results from an interaction between the relative accessibility of a particular category in a given context (i.e., comparative fit) and the fit between the category specificities and the social reality existent (i.e., normative fit). The relative accessibility of a given categorization will be dependent on the relevance and active selection of the different potential categories which are present in a given context. It has been postulated that this accessibility is affected by the degree to which individuals identify themselves (or not) with the relevant category or group. In turn, the fit or match between the specific category and the social context in which a given self-categorization will be salient, is dependent on two aspects of fit, namely comparative fit and normative fit (Oakes, 1987; for a detailed description see Turner, 1999).

To summarize, self-categorization can be "seen as a dynamic, context-dependent process, determined by comparative relations within a given context" (Turner, 1999, p. 13).

The main ideas of the theory postulate that: 1) individuals will represent themselves and others using different levels of self-categorization, based on their prior experiences, motives and the social context in which comparisons occur; 2) self-perception in terms of a salient social identity leads to depersonalization; and 3) it is depersonalization that causes intergroup behavior.

Although the social identity framework, in which the social identity and selfcategorization theories fall under, is undoubtedly a very prolific and rich approach to the conceptualization of intergroup relations, it does not come without certain limitations and even contradictions.

For many years, after the conceptualization of social identity theory and selfcategorization theory, it was assumed that intergroup relations were marked by intergroup differentiation and intragroup similarity effects. As such, individuals would conform to their ingroup's norms and beliefs and search for a positive 
distinction between their group and other relevant outgroups. However, since the 1970s (for example Doise, 1976), some "bizarre" results raised the possibility that differentiation and similarity could co-occur simultaneously.

The self-categorization theory assumed that through a process of self-categorization and self-stereotyping, individuals would depersonalize and become interchangeable members of their ingroup. Nonetheless, the research conducted by Deschamps (1984) about the possibility of co-variation between individual and collective differentiation, marks an important step in redefining certain aspects of the social identity approach, by assuming that inter-individual differentiation and intergroup differentiation can co-exist.

In his studies, Deschamps (1984) found that individuals who identify strongly with a group may also assume inter-individual differences within the group. Moreover, studies on the Primus Inter Pares effect (Codol, 1975) and the Black sheep effect (Marques, 1990; Marques \& Paez, 1994) also showed that, along with outgroup homogenization, intragroup differentiation occurs in many social contexts (for a detailed revision see Valentim, 2003).

Turner (1999) answers to these criticisms by stating that, in these cases, there is a redefinition of the ingroup in terms of subgroups. Hence, depending on the relevant social context, members of the ingroup could then be re-categorized as outgroup members, who are deviant of the normative beliefs of the ingroup. Their posterior inclusion in the ingroup, would depend on the existence of a more relevant outgroup, which would cause the similarities between the subgroups to be again accentuated, and creating the possibility of a new higher level self-categorization encompassing the deviant subgroup and the ingroup.

Although this explanation by Turner (1999) may seem valid at face value, it is important to refer that self-categorization theory always defines a functional antagonism, by which an individual self-definition cannot emerge when a collective self-definition is salient. Therefore, we should see these new lines of research not as opposite or contradictory to the social identity framework, but rather as complementary efforts to understand phenomena that were not hypothesized within social identity and self-categorization theories.

Another important limitation ascribed to social identity theory relates to the generalizations made from experiments using the minimal group paradigm. Although in both social identity theory and self-categorization theory, the authors assume that the classification and content of social categories have evaluative significance, they do not formulate thoroughly this classification or content.

In an attempt to make sense of the social world and the power relations existent within it, Deschamps (1982) proposes an analysis of social identities in which the differences in groups' status should be taken into consideration when studying 
intra and intergroup differentiation. Therefore, he proposes that the expression of social identities might differ depending on whether the groups are considered "dominant" or "dominated" within the bigger social structure.

This idea was formalized by Lorenzi-Cioldi (1988) in a series of studies, and it was concluded that indeed, the phenomena of inter-individual and intergroup differentiation are more associated with a dominant ingroup membership, than with a dominated ingroup membership. In further research developments, it was also shown that, depending on the relative groups' status under scrutiny, outgroup differentiation can occur (for an overview see Valentim, 2003, 2008).

Finally, it is important to note that both social identity theory and self-categorization theory assume ingroup identification as an epiphenomenon of social identity processes. This means that ingroup identification and the degree to which individuals identify more or less with their ingroups were not introduced in the conceptualization of both theories. Nevertheless, much research has shown (see, for example, Doosje, 1995; Doosje, Branscombe, Spears, \& Manstead, 1998; Branscombe, Doosje, \& McGarty, 2003, amongst others) that ingroup identification does affect the different reactions of ingroup members towards outgroup members. It is now widely acknowledged that high identifiers and low identifiers perceive an intergroup situation differently (especially a threatening one) and these differential perceptions lead to distinct behavioral consequences. Therefore, as Doosje (1995) refers "we would argue that it is important to incorporate individual differences with respect to group identification as an input variable" (p. 91) in the rationale for explaining and describing intergroup relations.

Furthermore, within the social identity approach, we may face a somewhat simplistic view regarding real life situations and the contexts in which different social identities may play a role. For example, the authors have not considered within their theoretical rationale the possibility of dual identities (e.g. second generation immigrants which belong by birth to the majority receiving group but also belong to a social group with a different cultural identity) or even situations in which two conflicting or concurring group identities may be at stake in a given context (e.g. the interaction between ethnic and gender identity). Within this line of thought, one may consider instances in which individuals may be confronted, at different times and situations, with multiple categorizations (Deschamps \& Doise, 1978) and, therefore, the possibility that more contextualized approaches may be necessary to understand the complexity of social life and, thus, the combination of different social identities at the same time. This may in turn prove important when understanding how different people react (cognitively, emotionally and behaviorally) to different groups and group members in social interactions. 
We can thus conclude that throughout the years, many theoretical developments have increased our understanding of the dynamics of intergroup relations and many phenomena, which, at first, were considered abnormal, are now well-described and have been incorporated within the social identity framework.

Nevertheless, up until now, the literature review has focused mainly on cognitive, motivational and perceptual explanations for intergroup relations and conflict. One may wonder if there are no emotional processes guiding the lives of groups. Although the main focuses of the different theories presented above do not explicitly state this, we would argue that emotions have a central role in understanding intergroup relations and the way individuals relate with each other in social life.

Given this, we will now turn our focus of analysis into theories of emotions and their potential role and functions on the field of intergroup relations.

\section{APPRAISAL THEORIES OF EMOTIONS}

Emotion is a difficult concept to define within the social psychology domain. As Fehr and Russell (1984) state, "everyone knows what an emotion is, until asked to give a definition. Then, it seems, no one knows" (p. 3).

Nevertheless, social psychologists have come to a general understanding of the word emotion, as "ongoing states of mind that are marked by mental, bodily or behavioral symptoms" (Parrott, 2001, p. 3). Additionally, it is now widely accepted that emotion can be distinguished from mood. In this line, the first "needs" to be about something or directed towards something (be it an object, person or situation), while the latter is a more general evaluation which does not need to be directed towards an object, being a more global evaluation that spreads beyond situations.

But why would it be relevant to study and understand emotions? When dealing with the functions of emotions, Keltner and Haidt (2001) have proposed a four-level analysis of the functions of emotions. According to these authors, at the individual level of analysis, emotions have two distinct functions. Namely, they may serve an informational function, in the sense that they "tell" the individual that there is a given situation or event which needs to be dealt with. Secondly, they may prepare the individual to react to a specific situation, even in the absence of awareness of the eliciting event.

At the dyadic or interpersonal level of analysis, emotions may have three different functions: 1) they may allow individuals to recognize others' emotions, beliefs and intentions, in way to coordinate efficiently social interactions; 2) emotional 
communication may help individuals respond to significant social events by evoking complementary and reciprocal emotions in others; and 3) they may serve as incentives or deterrents of others' reactions and social behavior (Keltner \& Haidt, 2001).

The third level of analysis refers to group life and Keltner and Haidt (2001) mention that emotions may, first, help individuals define group boundaries and identify ingroup and outgroup members. Within the ingroup, another function of emotions is the definition and negotiation of group-related roles and status and, finally, emotions may also lead individuals to solve or manage group-related problems.

The cultural level of analysis refers to the way in which emotions have been shaped by the cultural context. At this level, the functions of emotions are related to the processes by which individuals understand and accept their cultural identities, the way by which children learn the relevant norms and values within their culture and, finally, the possibility of maintaining and perpetuating cultural ideologies and power structures or relations.

Early approaches in the study of emotion assumed that they derived from bodily changes or from the arousal of the nervous sympathetic system associated with a cognitive recognition of the emotional state (for a detailed description see Parrott, 2001). However, these approaches lost popularity due to the lack of empirical support found during later years of research. These are, however, approaches that are seeing an upcoming, due to the development of new lines of research within the field of neurosciences.

In further developments, social psychologists came to a general understanding of emotions as a more complex phenomenon with multiple components which influence and are influenced by each other and that may be connected with other factors unrelated to emotion itself.

Following this rationale, the first appraisal theories of emotions emerged, having as a main goal the specification of the cognitive aspects of emotion. These theories have thus allowed for the description of the onset, subjective experience and consequences of emotions. Hereby, it is postulated that specific constellations of appraisals lead to distinct emotional responses, consisting of subjective experiences and specific action tendencies (for an overview see Scherer, Schorr, \& Johnstone, 2001).

The concept of appraisal was first defined by Arnold (1960) as a direct perceptual quality, which involves an evaluative perception of events or situations in terms of an individual's goals, needs, concerns and well-being.

First, it is important to distinguish between primary and secondary appraisals. The first are about whether something is or not relevant for the self. Secondary appraisals, in turn, occur within a limited number of dimensions and, here, different appraisal theories of emotion diverge in the number of dimensions or importance they attach to each dimension. However, one common dimension to several 
appraisal theories is motivational relevance (e.g. Frijda, 1986; Lazarus, 1991). This dimension refers both to a dispositional component (i.e. what individuals find important for themselves) and a situational component which makes events or stimuli become relevant to individuals. This is precisely what Frijda (2001) refers to as the laws of social meaning and concern within the study of emotion, meaning that the appraisal process and its consequences are adaptive and help individuals to attain their goals and needs.

Whenever a situation or stimulus elicits a given aggregate of specific appraisals, the subjective emotional experience will be processed in terms of specific forms of bodily arousal and action tendencies. It is then important to recognize that the distinct dimensions of the subjective emotional experience (feelings) are influenced by the appraisals leading to them. In addition, these same feelings can influence both the appraisals that first elicited the emotional situation and also the action tendencies associated with it.

This argument is made more clearly by Frijda (2001) who views emotions as changes in states of action readiness.

State of action readiness is a central notion in emotion. All emotions - all states, that is, that one would want to call 'emotions' - involve some change in action readiness (...) Several emotions can be unambiguously defined in terms of a particular form of action readiness; they can be defined in terms of some action tendency or some form of activation or lack thereof. (Frijda, 2001, p. 59-60)

This conceptualization of emotion, thus, allows researchers to analyze and distinguish emotions both in terms of their antecedents and consequences. For example, when a person appraises a negative event as an irreparable loss for which he or she is not responsible, they may feel grief and, in turn, feel instigated to let go and do nothing. However, when this same negative event is appraised as being the responsibility of someone who could control it, individuals may feel anger and thus act to change the situation, in a more vigorous way.

Summarizing, independently of the number of different theories within the emotions' appraisal domain, it is clear that conceptualizing the nature of emotion as a multi-component phenomenon clearly benefited the study of emotion within social psychology. The basic premise that different dimensions concur and diverge to produce distinct emotional reactions to specific stimuli and events, sets a fruitful framework from which to look at emotion and conceptualize the ways in which they influence the social life of individuals.

We will now detain ourselves in the description of an extension of the appraisal theories of emotion to the field of intergroup relations. 


\section{INTERGROUP EMOTIONS THEORY}

In a famous study by Cialdini, Borden, Thorne, Walker, Freeman and Sloan (1976) it was shown that people "bask in reflected glory" through their association with successful others, even though they were not personally involved in the others' success. Individuals who saw their university team win, would strive to associate themselves with this success source, by, for example, using terms as "we won", amongst others.

At the time, the role of emotions was not referred to in these experiments, but this article, amongst others, set the basis for a new conceptualization of the ways in which people associate with others (or groups) to enhance their self-image, an argument which is also in line with the assumptions of social identity theory.

This is a very clear example of instances when one derives positive feelings from the association with others. We become ecstatic over the victories of our sports teams; we are happy when our political party wins the elections; we feel proud when our university is evaluated number one on a European university ranking, amongst many other examples. But we might also derive negative feelings from our shared memberships. We can get angry or frustrated when our beloved group's image is at stake, or we might experience fear about the terrorist threat due to our membership in the Western world, or feel guilty about misdeeds carried out by other ingroup members in the past.

It is this general awareness that emotions may arise not only from interindividual instances of behavior or comparison, but rather from intra and/or intergroup processes and relations, that sets the background for the possibility of studying emotions as intergroup phenomena. In this line, Smith (1993) formulated the intergroup emotions theory in an attempt to refine the traditional conceptualizations of intergroup behavior and, especially, negative forms of prejudice and discrimination.

In its traditional forms (see for example Allport, 1954; Hogg \& Abrams, 1988; amongst others), prejudice was conceived as an attitude towards outgroups based on a positive or negative evaluation of the attributes associated with these groups. Following this perceptual evaluation of outgroups in terms of a dichotomous differentiation, discrimination would then materialize and represent this general estimation of a group's value through their negative inherent attributes.

Although these theories have shaped, for years, the study of prejudice and discrimination within the field of psychology and have brought about many interesting and relevant findings, they do present some limitations. Firstly, this attitude-based model of discrimination could not account for the multitude of distinct reactions to relevant outgroup members. Within the attitude model, prejudice could only 
be perceived as a negative evaluation of groups who have negative characteristics ${ }^{5}$. However, is this true? Do we react in the same way to outgroups who make us fearful and groups who make us angry? The clear answer is no, and although much research has showed that there are, indeed, differentiated reactions to outgroups, the rigidity of the attitude-based model does not allow us to account for these differences.

Secondly, within the attitude-based model of prejudice it is usually assumed that we learn certain negative affective responses through social conditioning, which determines automatically our reactions towards members of devalued groups, regardless of the social context or circumstances. But then, how could one explain instances in which a group, who was a fierce enemy of ours in the past, becomes an allied and significant friend? How could one explain the shifts in discrimination towards different outgroups through time? More recent theories within the attitude domain have tried to make sense of these occurrences through the advent of the possibility of multiple evaluations of objects. But given the classical view of attitudes as an organizing and uniformizing principle of reality independent of contexts, these have not been very successful.

Thirdly, situations in which we are ambivalent and hold incompatible "attitudes" regarding the same group have proven to be problematic within a unidimensional perspective of the evaluation process. The classical views only consider the possibility of ambivalence between components of the attitude, but in reality, there is the possibility of multiple incompatible evaluations towards the same group.

As mentioned above, these limitations, amongst others, of the attitudinal perspective of prejudice and discrimination, lead researchers in recent years to develop new lines of investigation that would allow for "a view of intergroup relations as more group, situation and context specific than that allowed by earlier approaches" (Mackie, \& Smith, 2003, p. 1). These new approaches to the study of prejudice and discrimination would thus benefit from a conceptualization of emotion as a theoretical basis for comprehending prejudice in several ways. For example, affective reactions to outgroup members seem to outlast the cognitive components of prejudice; affect also seems closer related to behavior than its cognitive antecedents; and emotions can also better explain instances of 'hot' discrimination (for a review see Mackie \& Smith, 2003).

Moreover, within the appraisal of emotions approach, at the inter-individual level, emotion conceptualizations provide a conceptual structure similar to the one proposed in attitude theory. Appraisal theories of emotion postulate that cognitive evaluations produce emotions which in turn lead to behavior, in the same line that beliefs cause attitudes and the latter cause behavior. But while attitudes represent a

5 An important note here relates to the idea that individuals can also evaluate positively outgroups and perceive them to have positive characteristics. This positive prejudice is, nonetheless, usually kept on a secondary level of analysis, since negative prejudices are the ones which may have worst consequences for intergroup relations. 
general, more or less indistinct positive or negative evaluation, emotions contribute to a better understanding of social behavior, given that it is assumed that they allow for more differentiation and specificity in explaining behavior.

Finally, the self-regulatory nature of emotions may also contribute to a better explanation of inter-individual (as revised in the previous section) and social processes and relations. Since it is assumed that different emotions are associated with distinct action tendencies (i.e. if we are fearful, we run away, if we are happy we react effusively, etc.), they may also function to self-regulate and act accordingly towards outgroups in relation to what our emotions tell us.

So, what intergroup emotions theory proposes is to take a step further in the conceptualization of emotions as affecting and even regulating intergroup relations.

From this perspective, intergroup emotions involve the impulse, desire, or tendency to take action aimed at bringing groups closer together, moving them further apart, changing or justifying a status hierarchy, eliminating a competitor, or nurturing an ally - all in the service of maintaining the ingroup. (Mackie, Silver, \& Smith, 2004, p. 228)

Intergroup emotions theory relies on social identity and self-categorization theories, as well as appraisal theories of emotions at the individual and inter-individual level, to explain when emotions are likely to occur and influence intergroup processes and relations.

When a specific social identity is made salient, individuals see themselves more in terms of their group membership than in terms of their individual identities, and their action tendencies will reflect this group level self-categorization. Most importantly, individuals will not only "see" themselves in terms of this social identity, but they will also "feel" in terms of it.

In intergroup contexts, we may also expect that differentiated intergroup behaviors occur because specific intergroup emotions have been triggered by particular group-based appraisals. Intergroup situations eliciting fear or anxiety responses may well prompt a motive to escape or avoid the outgroup, whereas anger will generate a willingness to attack or aggress against the outgroup. Disgust and contempt are also more likely to activate avoidance behaviors, while resentment and frustration may lead group members to take actions against the outgroup. (Devos, Silver, Mackie, \& Smith, 2003, p. 113)

In other words, when individuals' group membership and thus social identity is made salient in a given context, appraisals of the situation in terms of social identities will occur and lead to collective-based action tendencies. Therefore, 
individuals' behavior can be explained in terms of group-based concerns, motives and goals, rather than individual-based concerns. Furthermore, this behavior is not random or a general inclination to "do or not do" one general kind of action. Instead, what intergroup emotions theory postulates is that different emotional reactions derived from group memberships will lead to distinct action tendencies.

This is the rationale used to explain why, for example, ingroup members avoid or confront relevant outgroups, depending on the intergroup context. When the ingroup is appraised as strong and holds an advantaged position over the outgroup and there is a situational threat against the ingroup, the most likely emotional experience is anger, which will lead to the desire of aggressing and confronting the outgroup (Iyer \& Leach, 2008). However, when the ingroup is appraised as relatively powerless or lacking the resources to deal with a threat from an outgroup, fear is the most likely emotional experience, leading to avoidance or escape from the situation (Devos et al., 2003).

It is, therefore, very important to reinforce that the theory of intergroup emotions conceptualizes intergroup emotions as differentiated reactions to outgroups, which are relational in their nature, context specific, affected by institutionalized power structures between groups and derived from subjective interpretations of the situations in which they come to existence (Mackie \& Smith, 2003).

Over the past years, there has been much research providing indirect and direct evidence for the validity and applicability of this theory (for a detailed review see Devos et al., 2003). By now, there are three well documented aspects of the phenomenon of emotions that can make them distinctively intergroup in nature, as opposed to individual or inter-individual emotions.

The first postulate of intergroup emotions theory is that these emotions are dependent on the psychological identification with a group. Therefore, it is argued that emotions will be affected by the process of identification and the quality and even quantity of that identification. The authors (Mackie \& Smith, 2003; Smith, 1993) further extend the conceptualization of ingroup identification as being distinct from membership in a group, in the sense that the first carries within it not only the awareness of belonging to a group, but also the affective significance attached to this membership, much like Tajfel (1972) had previously defended.

Secondly, the theory postulates that intergroup emotions arise from group rather than personal concerns. It is thus the motives, goals and needs (i.e. concerns) of the ingroup that determine the emotional experience most likely to occur, independently of how these concerns relate directly with the individual's well-being or involvement in the situations or interactions eliciting them.

Finally, the authors envisage intergroup emotions as functionally regulating intergroup interactions between ingroups and outgroups in the sense that they modulate the cognitive, evaluative and behavioral reactions in intergroup settings. 
Summarizing, intergroup emotions theory augments our understanding of intergroup relations and conflict, through the conceptualization of these emotions as phenomena which shape and influence distinct social encounters between groups, as well as the outcomes of such encounters, in a more differentiated and context specific way than previous approaches were able to.

\section{RECOMMENDATIONS FOR FUTURE RESEARCH}

Within the present manuscript, we have highlighted the state-of-the-art literature regarding theoretical and empirical approaches to the study of intergroup relations and the role of emotions for instances of intergroup prejudice, discrimination and conflict. Although in recent years we have seen a vast body of work within this topic, we believe that further research is needed to provide us with more insights into such a complex and dynamic domain within social psychology.

One of our first recommendations pertains to the fact that most of the present literature review falls within the scope of analysis of unique social identities (e.g. considering only national or religious identity), thus not considering the role of dual identities or even multiple social categorizations (Deschamps \& Doise, 1978). For instance, one may consider instances in which different social identities may be at skate at the same time and considering the ways in which such specific identities are made salient or even how combinations of social identities may influence the way individuals interact with each other and the way in which different emotions may arise is of utmost importance. For example, Kuppens and Yzerbyt (2012) have found that salience of a given social identity (such as woman $v s$ young adults $v s$ social sciences students social identities) may arouse different emotional reactions towards Muslims. Therefore, we argue for a more refined approach regarding the study of multiple social identities when understanding the role of emotions for intergroup relations.

Furthermore, one must also consider the specific social positions and perspectives of different social groups, which may elicit different emotional reactions towards different outgroups. For example, it is known that group-based anger for collective disadvantage against the ingroup may emerge when group members feel there is a possibility of social change, whereas when this possibility is lacking, group members are more likely to feel sadness (e.g. Smith, Cronin, \& Kessler, 2008).

Another possibility for future research is to include a longitudinal perspective when studying the role of emotions for intergroup relations. Understanding how different social identities may develop through time and how different emotional 
reactions may arise due to socio-economic or even social status changes within society is also an important line of development that will shed a light into the dynamics of emotions and intergroup relations.

Related to the previous point is also the fact that certain group memberships may change throughout time. For example, age categorizations change across the lifespan and, associated with these, different forms of perceiving yourself and the age group to which you belong to may affect the way in which you interact with other individuals that belong (or not) to different age groups. Thus, understanding how social identities naturally change across time is also important to understand the consequences of distinct emotional reactions depending on such group memberships and the degree of identification with these groups. Given that age categorization is a special kind of group membership, analyzing such topics in a longitudinal way may also prove very enriching for understanding new forms of discrimination.

Finally, we believe it is important to discuss the practical implications of the study of emotions for intergroup relations. Drawing from the literature previously presented, we have seen that different emotions may shape different social interactions between individuals. However, little is known regarding the possibility of using emotions to prevent and reduce discrimination in different contexts.

We further recommend researchers to refine and complement their analysis of emotions at the intergroup level, through the inclusion of more emotional experiences in their conceptualization of intergroup relations and different methodologies, such as interviews, focus groups, physiological measures and behavioral approaches. While most of the research focuses on self-reported assessments of emotions, these may be influenced by factors such as social desirability or other perceptive biases of emotional reactions. Thus, we believe the field will be enriched by further insights into the full determinants of group-based emotions, their antecedents and distinct consequences if other ways of addressing and analyzing emotions are developed in the future.

We believe these suggestions underline the richness and usefulness of the theoretical conceptualizations and findings reported throughout this manuscript and that is why they should be considered in future endeavors within the domain of intergroup relations.

\section{CONCLUDING REMARKS}

Throughout this manuscript we have presented some of the most influential and fertile theories within the field of intergroup relations. We have followed a rationale by which we introduced new insights and conceptualizations of intergroup relations, conflict and emotion developed over the years, and which have contributed 
to augment our understanding of intergroup phenomena. At the moment, much research is being conducted under the topic of intergroup relations and emotions. The present manuscript aims to have given a general overview of the most used frameworks within this field, while also contributing to an integration of the different perspectives used within the field of intergroup relations.

\section{REFERENCES}

Ackerman, N., \& Jahoda, M. (1950). Anti-semitism and emotional disorders: A psycho-analytic interpretation. New York: Harper.

Adorno, T. W., Frenkel-Brunswick, E., Levinson, D. J., \& Sanford, R. N. (1950). The authoritarian personality. New York: Harper.

Ajzen, I., \& Fishbein, M. (1977). Attitude-behavior relations: A theoretical analysis and a review of empirical research. Psychological Bulletin, 84, 888-918.

Allport, G. W. (1954). The nature of prejudice. Cambridge, MA: Addison Wesley.

Amâncio, L. (2002). Identidade social e relações intergrupais. In J. Vala \& M. B. Monteiro (Coords), Psicologia social [Social psychology] (pp. 387-409) [5 ${ }^{\text {th }}$ Ed.]. Lisboa: Fundação Calouste Gulbenkian.

Arnold, M. B. (1960). Emotion and personality (2 Vols). New York: Columbia University Press.

Branscombe, N., Doosje, B., \& McGarty, C. (2003). Antecedents and consequences of collective guilt. In D. Mackie \& E. Smith (Eds.), From prejudice to intergroup emotions: Differentiated reactions to social groups (pp. 49-66). New York: Psychology Press.

Cialdini, R. B., Borden, R. J., Thorne, A., Walker, M. R., Freeman, S., \& Sloan, L. R. (1976). Basking in reflected glory; Three (football) field studies. Journal of Personality and Social Psychology, 34, 366-375. doi:10.1037/0022-3514.34.3.366

Codol, J. P. (1975). On the so-called "Superior conformity of the self" behavior: Twenty experimental investigations. European Journal of Social Psychology, 5, 457-501. doi:10.1002/ejsp.2420050404

Derks, B., Van Laar, C., \& Ellemers, N. (2007). Social creativity strikes back: Improving motivated performance of low status group members by valuing ingroup dimensions. European Journal of Social Psychology, 37, 470-493. doi:10.1002/ejsp.375

Deschamps, J. C. (1982). Social identity and relations of power between groups. In H. Tajfel (Ed.), Social identity and intergroup relations (pp. 85-98). Cambridge: Cambridge University Press.

Deschamps, J. C. (1984). Identité sociale et différenciations individuelles. Cahiers de Psychologie Cognitif, 4, 449-474.

Deschamps, J. C., \& Doise, W. (1978). Crossed category memberships in intergroup relations. In H. Tajfel (Ed.), Differentiation between social groups (pp. 141-158). Cambridge: Cambridge University Press.

Devos, T., Silver, L. A., Mackie, D. A., \& Smith, E. R. (2003). Experiencing intergroup emotions. In D. Mackie \& E. Smith (Eds.), From prejudice to intergroup emotions: Differentiated reactions to social groups (pp. 111-134). Sussex: Psychology Press.

Doise, W. (1976). L'articulation psychosociologique et les relations entre groupes. Bruxelles: De Boeck.

Doosje, B. (1995). Stereotyping in intergroup contexts (Unpublished doctoral dissertation). University of Amsterdam, the Netherlands. 
Doosje, B., Branscombe, N., Spears, R., \& Manstead, A. (1998). Guilty by association: when one's group has a negative history. Journal of Personality and Social Psychology, 75(4), 872-886. doi:10.1037/0022-3514.75.4.872

Ellemers, N. (1993). The influence of socio-structural variables on identity management strategies. European Review of Social Psychology, 4, 22-57. doi:10.1080/14792779343000013

Fehr, B., \& Russell, J. A. (1984). Concept of emotion viewed from a prototype perspective. Journal of Experimental Psychology: General, 113, 464-486. doi:10.1037/0022-3514.60.3.425

Frijda, N. H. (1986). The emotions. Cambridge, England: Cambridge University Press.

Frijda, N. H. (2001). The laws of emotions. In W. G. Parrott (Ed.), Emotions in social psychology: Essential readings (pp. 57-70). Philadelphia: Psychology Press.

Hogg, M. A., \& Abrams, D. (1988). Social identifications: A social psychology of intergroup relations and intergroup processes. London: Routledge.

Iyer, A., \& Leach, C. (2008). Emotion in intergroup relations. European Review of Social Psychology, 19, 86-125. doi:10.1080/10463280802079738

Keltner, D., \& Haidt, J. (2001). Social functions of emotions at four levels of analysis. In W. G. Parrott (Ed.), Emotions in social psychology: Essential readings (pp. 175-184). Philadelphia: Psychology Press.

Kuppens, T., \& Yzerbyt, V. Y. (2012). Group based emotions: The impact of social identity on appraisals, emotions and behaviors. Basic and Applied Social Psychology, 34, 20-33. doi: 10.1080/01973533.2011.637474

Lazarus, R. S. (1991). Emotion and adaptation. New York: Oxford University Press.

Lerner, M. J. (1980). Belief in a just world: A fundamental delusion. New York: Plenum.

Lorenzi-Cioldi, F. (1988). Individus dominants et groupes dominés. Grenoble: Presses Universitaires de Grenoble.

Mackie, D. M., \& Smith, E. R. (Eds.). (2003). From prejudice to intergroup emotions: Differentiated reactions to social groups. New York: Psychology Press.

Mackie, D., Silver, L., \& Smith, E. (2004). Intergroup emotions: Emotion as an intergroup phenomenon. In L. Tiedens \& C. Leach (Eds.), Studies in emotion and social interaction: The social life of emotions (pp. 227-245). Cambridge: Cambridge University Press.

Marques, J. (1990). The black-sheep effect: Out-group homogeneity in social comparison settings. In D. Abrams \& M. A. Hogg (Eds.), Social identity theory: Constructive and critical advances (pp. 131-151). NY: Harvester Wheatsheaf.

Marques, J., \& Paez, D. (1994). The "black sheep effect”: Social categorization, rejection of ingroup deviates, and perception of group variability. European Review of Social Psychology: Vol. V (pp. 37-68). Chichester, UK: John Wiley \& Sons.

Oakes, P. J. (1987). The salience of social categories. In J. C. Turner, M. A. Hogg, P. J. Oakes, S. D. Reicher, \& M. S. Wetherell (Eds.), Rediscovering the social group: A self-categorization theory. Oxford: Blackwell.

Parrott, W. G. (Ed.). (2001). Emotions in social psychology: Essential readings. Philadelphia: Psychology Press.

Pennekamp, S. F. (2008). Dynamics of disadvantage: Uncovering the role of group-based anger (Unpublished doctoral dissertation). University of Amsterdam, the Netherlands.

Scherer, K. R., Schorr, A., \& Johnstone, T. (2001). Appraisal processes in emotion: Theories, methods, research. New York: University Press.

Sherif, M. (1962). Intergroup relations and leadership. New York: Willey. 
Sherif, M. (1966). In common predicament: Social psychology of intergroup conflict and cooperation. Boston: Houghton Mifflin.

Sherif, M., Harvey, O. J., White, B. J., Hood, W. R., \& Sherif, C. W. (1961). Intergroup cooperation and conflict: The Robbers cave experiment. Norman, OK; University Book Exchange.

Smith, E. R. (1993). Social identity and social emotions: Toward new conceptualization of prejudice. In D. M. Mackie \& D. L. Hamilton (Eds.), Affect, cognition and stereotyping (pp. 297-315). San Diego, CA: Academic Press.

Smith, H. J., Cronin, T., \& Kessler, T. (2008). Anger, fear or sadness: Faculty members' emotional reactions to collective pay disadvantage. Political Psychology, 29(2), 221-246.

Smith, H. J., Spears, R., \& Hamstra, I. (1999). Social identity and the context of relative deprivation. In N. Ellemers, R. Spears, \& B. Doosje (Eds.), Social identity: Context, commitment, content (pp. 205-229). Malden, MA: Blackwell Publishers.

Stephan, W. G., \& Stephan, C. W. (1996). Intergroup relations. USA: Westview Press.

Stouffer, S. A., Suchman, E. A., DeVinney, L. C., Star, S. A., \& Williams, R. M. (1949). The American soldier: Vol. 1. Adjustment during army life. Princeton, NJ: Princeton University Press.

Tajfel, H. (1970). Experiments in intergroup discrimination. Scientific American, 223(5), 96-102.

Tajfel, H. (1972). La categorization sociale. In S. Moscovici (Ed.), Introduction à la psychologie sociale: Vol. I (pp. 272-302). Paris: Larousse.

Tajfel, H. (1978). The achievement of inter-group differentiation. In H. Tajfel (Ed.), Differentiation between social groups (pp. 77-100). London: Academic Press.

Tajfel, H., \& Turner, J. C. (1979). An integrative theory of social conflict. In W. G. Austin \& S. Worchel (Eds.), The social psychology of intergroup relations (pp. 33-47). Montery, CA: Brooks-Cole.

Tajfel, H., \& Turner, J. C. (1986). The social identity theory of intergroup conflict. In S. Worchel \& W. G. Austin (Eds.), Psychology of intergroup relations (pp. 7-24). Chicago, IL: Nelson-Hall.

Tajfel, H., \& Turner, J. C. (2001). An integrative theory of intergroup conflict. In M. A. Hogg, \& D. Abrams (Eds). Intergroup relations: Essential readings. USA: Psychology Press.

Tajfel, H., Flament, C., Billig, M., \& Bundy, R. P. (1971). Social categorization and intergroup behavior. European Journal of Social Psychology, 1, 149-178. doi:10.1002/ejsp.2420010202

Turner, J. C. (1981). The experimental social psychology of intergroup behavior. In J. C. Turner, \& H. Giles (Eds.), Intergroup behavior (pp. 66-101). Chicago: University of Chicago Press.).

Turner, J. C. (1999). Some current issues in research on social identity and self-categorization theories. In N. Ellemers, R. Spears, \& B. Doosje (Eds.), Social identity: Context, commitment, content (pp. 6-34). MA: Blackwell.

Turner, J. C., \& Reynolds, K. J. (2001). The social identity perspective in intergroup relations: Theories, themes, and controversies. In R. Brown \& S. Gaertner (Eds.), Blackwell Handbook of Social psychology: Intergroup processes. MA: Blackwell.

Turner, J. C., Hogg, M. A., Oakes, P. J., Reicher, S. D., \& Wetherell, M. S. (Eds.). (1987). Rediscovering the social group: A self-categorization theory. Oxford: Blackwell.

Vala, J., Brito, R., \& Lopes, D. (1999). Expressões do racismo em Portugal [Expressions of racism in Portugal]. Lisboa: Imprensa de Ciências Sociais.

Valentim, J. P. (2003). Identidade e lusofonia nas representações sociais de portugueses e de africanos [Identity and lusophony in the social representations of Portuguese and Africans] (Unpublished doctoral dissertation). Coimbra, Universidade de Coimbra.

Valentim, J. P. (2008). Identidade pessoal e social: entre a semelhança e a diferença [Personal and social identity: between similarity and difference]. Psychologica, 47, 109-123. 
Valentim, J. P. (2010). Sherif's theoretical concepts and intergroup relations studies: notes for a positive interdependence. Psychologica, 52(2), 585-598.

Vanneman, R. D., \& Pettigrew, T. (1972). Race and relative deprivation in the urban United States, Race, 13, 461-486. doi:10.1177/030639687201300404

Walker, L., \& Smith, H. J. (2002). Relative deprivation: Specification, development and integration. Cambridge: Cambridge University Press. 